UDC 94(47).083

Submitted: 07.09.2017

LBC 63.3(2)53

Accepted: 10.11.2017

\title{
THE COURT STABLE DEPARTMENT AND HIS IMPERIAL MAJESTY'S OWN GARAGE IN 1917
}

\author{
Petr N. Gordeev \\ Herzen State Pedagogical University of Russia, Saint Petersburg, Russian Federation
}

\begin{abstract}
The article is based on archival documents, the majority of which are firstly introduced into the scientific circulation. The author studies the history of the Court Stable Department and the adjacent Garage of His Majesty during the Russian revolution. The February events stunned the management team of the servants of the Stable office: head of the department A.A. Grinwald was arrested, and head of the household A.A. Schildknecht was killed. During the period of the Provisional Government that establishment of the former Ministry of the Court was consistently supervised by three people, distant from both the cavalry and the automotive business: journalist F.P. Kupchinsky, a member of the State Duma V.I. Dziubinsky and journalist E.A. Frenkel. In their activity they had to take into the account diverse requirements of the representatives of the lower employees, who had organized their Committee. By the time of the October revolution it was planned to convert the Court Stable Department into the Car-Stable facility, but it remained unclear whether it would be directly under the government, or it would remain a part of the Commissariat of the Provisional government of the former Ministry of the Court. After the Bolsheviks coming to power, the employees chose as their leader one of the senior officers of the Department, Lieutenant Colonel A.G. Bolin, who together with the newly appointed by the government Commissioner was to conduct a further reform of the stables facility and the Garage.

Key words: Court Stable Department, His Imperial Majesty's Own garage, Ministry of the Court, Russian revolution of 1917, F.P. Kupchinsky, V.I. Dzyubinsky, E.A. Frenkel.

Citation. Gordeev P.N. The Court Stable Department and His Imperial Majesty's Own Garage in 1917. Vestnik Volgogradskogo gosudarstvennogo universiteta. Serija 4, Istorija. Regionovedenie. Mezhdunarodnye otnoshenija [Science Journal of Volgograd State University. History. Area Studies. International Relations], 2017, vol. 22, no. 6, pp. 87-98. (in Russian). DOI: https://doi.org/10.15688/jvolsu4.2017.6.9
\end{abstract}

\section{ПРИДВОРНАЯ КОНЮШЕННАЯ ЧАСТЬ И СОБСТВЕННЫЙ ЕГО ИМПЕРАТОРСКОГО ВЕЛИЧЕСТВА ГАРАЖ В 1917 ГОДУ}

\author{
Пётр Николаевич Гордеев \\ Российский государственный педагогический университет им. А.И. Герцена, \\ г. Санкт-Петербург, Российская Федерация
}

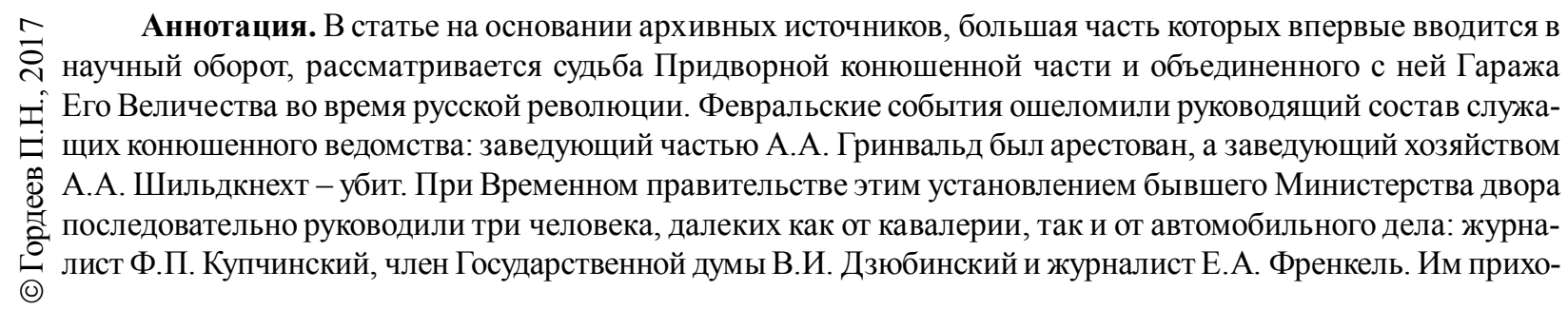


дилось в своей деятельности учитывать разнообразные требования представителей низших служащих, организовавших свой комитет. Ко времени Октябрьской революции было намечено преобразование Придворной конюшенной части в Автоконюшенную базу, но оставалось неясным, будет ли она состоять непосредственно при правительстве или останется в составе Комиссариата Временного правительства над бывшим Министерством двора. После прихода к власти большевиков служащие избрали своим руководителем одного из старших офицеров ведомства, подполковника А.Г. Болина, которому, вместе с назначенным новой властью комиссаром, и предстояло проводить дальнейшее реформирование Конюшенной части и Гаража.

Ключевые слова: Придворная конюшенная часть, Собственный Его Императорского Величества гараж, Министерство императорского двора (МИДв), революция 1917 г., Ф.П. Купчинский, В.И. Дзюбинский, Е.А. Френкель.

Цитирование. Гордеев П. Н. Придворная конюшенная часть и собственный Его Императорского Величества гараж в 1917 году // Вестник Волгоградского государственного университета. Серия 4, История. Регионоведение. Международные отношения. - 2017. - T. 22, № 6. -C. 87-98. - DOI: https://doi.org/10.15688/jvolsu4.2017.6.8

Придворная конюшенная часть была одним из старейших подразделений МИДв; ее история восходила к Конюшенному приказу, возникшему при дворе Ивана Грозного [1, с. 20]. В предреволюционное время в ее состав входили Канцелярия, Верховое отделение, Отделение русской упряжи и Отделение шорной упряжи. В 1912 г. управляющему частью был подчинен (однако «на правах широкой автономии») «Собственный Его Императорского Величества гараж» [11, с. 153] - новое придворное учреждение, появившееся в царствование Николая II [5, с. 15-74; 9, с. 203-216]. Общая численность служащих конюшенного ведомства (без Гаража) достигала в 1917 г. почти 600 человек [20, л. 17-23 об., 27-28], а на его содержание в смете МИДв на 1917 г. было ассигновано 1242180 руб. (против 1064195 руб., отпущенных в 1916 г.). Отдельной строкой в бюджете МИДв было прописано содержание Собственного Его Императорского Величества гаража, на что в 1917 г. (как и в предшествующем году) планировалось израсходовать 120000 руб. [32, л. 60-60 об.].

До падения монархии значительная часть руководства Придворной конюшенной части состояла из офицеров немецкого происхождения. Канцелярией части заведовал генерал-лейтенант А.Х. Палеолог, хозяйством - полковник А.А. Шильдкнехт, Отделением русской упряжи управлял Л.А. Гентер с двумя старшими конюшенными офицерами А.А. Зеестом и П.А. Обермиллером [4, с. 59]. Инспектором Гаража состоял капитан 1-го ранга Д.В. фон Ден [18, л. 62]. Возглавлял же ведомство с 1897 г. эстляндский дворянин, обершталмейстер, генерал от кавалерии Артур-
Отто-Мориц Александрович фон Гринвальд (1847 г. р., выпускник Дерптского университета, начал службу в лейб-гвардии Кирасирском полку еще в 1866 г., участвовал в Хивинском походе 1873 г., был женат на графине Анне Тизенгаузен [17, л. 33-53 об.]). Это позволяет предположить, что в напряженных отношениях, сложившихся в 1917 г. между «низами» и «верхами» конюшенной части, сыграл роль и национальный, антинемецкий фактор, вообще занимавший довольно заметное место в событиях Февральской революции.

Отметим также, что руководящий состав установления был крайне деморализован падением монархии и неопределенностью их собственной судьбы. В значительной степени это было обусловлено событиями Февральской революции, в ходе которой А.А. Гринвальд был арестован, а А.А. Шильдкнехт убит [6, с. 28-29]. В прессе начали появляться сообщения о том, что «Придворно-конюшенную часть в значительной степени предполагается упразднить. Конюшни будут ликвидированы и будет сохранено лишь известное количество экипажей и лошадей для будущего носителя высшей власти в империи при новом государственном строе» [38, с. 3]. Писательница С.И. Смирнова-Сазонова, автор известного дневника, 9 марта беседовала со своим родственником, старшим конюшенным офицером А.В. Давыдовым: «Он вчера приехал с фронта. Явился к Палеологу, спрашивает, зачем его вызвали, что он будет здесь делать. Тот, совсем подавленный, сказал, что сейчас остается только одно - выжидать.

- Да черт их возьми совсем! - крикнул Давыдов. Чтобы я стал подавать карету Ми- 
люкову!? Я подам карету царю, а не этим думск[им] господам» [33, л. 166].

Первые несколько недель «свободной России» в конюшенном ведомстве оказались тесно связаны с личностью, казалось бы, довольно далекого от иппологии человека - журналиста Филиппа Петровича Купчинского. Родившийся в 1881 г. в семье чиновника судебного ведомства, он успел отметиться на разных жизненных поприщах: писал стихи и эссе (вполне графоманского свойства) под влиянием публициста правых взглядов В.В. Ярмонкина, учился на юридическом факультете Петербургского университета в одно время с А.Ф. Керенским, был военным корреспондентом в Порт-Артуре и затем пленным в Японии, запустил в своих книгах словечко «герои тыла», начал печатно обвинять A.М. Стесселя в падении крепости (а тот Купчинского - в предательском поведении во время плена), стал пламенным певцом мятежа во время первой революции, переписывался с Л.Н. Толстым (у которого ранее не находил «ни одной новой мыслишки»), в годы Первой мировой вновь стал военным корреспондентом, а в марте 1917 г. руководил эксгумацией, перевозкой из Царского Села и сожжением трупа Г.Е. Распутина. Последнее дело он совершил в качестве уполномоченного Временного правительства по делам бывшей Придворной конюшенной части. История его появления в этой должности довольно туманна. Во время Февральской революции Купчинский перегнал автомобили Собственного Его Величества Гаража из Царского Села в Петроград, получив 1 и 2 марта полномочия по комплектованию автомобильной базы Временного комитета Государственной думы; 7 марта министром-председателем Г.Е. Львовым ему было поручено управление всем имуществом конюшенного ведомства. Однако назначенный 8 марта комиссаром над бывшим МИДв Ф.А. Головин не сработался с Купчинским и 30 марта предложил заведование Придворной конюшенной частью и Гаражом члену Государственной думы В.И. Дзюбинскому. Последующие две недели Купчинский отчаянно боролся за свое место, написал два письма Г.Е. Львову, в которых подчеркивал свои заслуги и обрисовывал планы выделения «автомобильной базы» (бывше- го Гаража Его Величества) в самостоятельное учреждение с подчинением непосредственно правительству, но все оказалось бесполезным: 16 апреля Филипп Петрович вынужден был сдать дела назначенцу Головина $[7$, с. 48-79].

Новым руководителем бывшей Придворной конюшенной части в статусе уполномоченного (сам он, впрочем, называл себя, как и А.А. Гринвальд, «заведующим» $[15$, л. 1]) комиссара над бывшим МИДв стал член III и IV Государственных дум (от Тобольской губернии), трудовик Владимир Иванович Дзюбинский. Как и его предшественник, Дзюбинский, выступая в Думе по вопросам развития Сибири и на темы о нуждах крестьянства, был далек от круга проблем, связанных с деятельностью возглавляемого им теперь установления [12, с. 163-164]. Тем не менее Головин ранее уже делал попытку привлечь его к работе в структурах Комиссариата (видимо, на основании личного знакомства). 20 марта от имени комиссара (и за подписью его помощника П.М. Макарова) было отправлено служебное письмо М.В. Родзянко, в котором говорилось: «В ведение Государственного хозяйства переходят имущества чрезвычайной ценности, для упорядочения которых и охраны необходимо привлечь общественные силы, ввиду чего я нахожу крайне желательным и покорнейше прошу Вас привлечь с своей стороны для этой цели членов Государственной Думы: Владимира Ивановича Дзюбинского, Михаила Дмитриевича Калугина и Михаила Ивановича Арефьева, согласием которых я уже заручился». 26 марта последовал ответ М.В. Родзянко - ВКГД «не признал возможным командировать» указанных членов Думы «для участия в работах по передаче государству имуществ, находящихся в заведывании бывшего Министерства Императорского Двора» [24, л. 120, 145]. Однако, несмотря на возражения терявшего свое влияние ВКГД, указанные депутаты, за исключением Арефьева, в итоге все же оказались на руководящих постах в бывшем придворном ведомстве (Калугин возглавил бывший Придворный оркестр [30, л. 48, 55]).

Дзюбинскому, представителю левых политических сил, имевшему за плечами революционное прошлое, было нелегко найти об- 
щий язык с проникнутыми монархическим духом высшими служащими бывшей Придворной конюшенной части, преимущественно состоявшими в штаб-офицерских чинах. Впрочем, их отношения могли принимать самые неожиданные обороты, которые иллюстрирует уже упоминавшийся дневник С.И. Смирновой-Сазоновой. Если писательница, следившая за происходившим в конюшенном ведомстве, беспокоясь о судьбе А.В. Давыдова, 13 марта грустно размышляла: «Куда он, кавалерист и барин стар[ого] закала, теперь пристроится? Конюшен[ное] ведомство раскассируют, и он останется на улице» [33, л. 180], то 20 мая появилась такая запись: «Давыдова призывал на днях комиссар Дзюбинский и предложил ему подать в отставку или ехать на фронт. Давыдов и от того, и от другого отказался. А через 2 дня неожидан[ная] перемена. Дзюбинский опять его призвал и не только оставляет его на службе, но даже с повышением, его делают заведующим хозяйством. Мы, говорит, узнали, что вы не ладили с своим начальством. Ему, очевидно, от конюхов стало изв[естно], каким гонениям Давыдов подвергался от Штауфа ${ }^{1}$. Теперь Штауф оказал ему посмертную услугу. За борьбу с эт[им] немцем нов[ое] правительство оставляет Давыдова на службе» [34, л. 83].

Тем временем стали проявляться радикальные настроения низших служащих бывшей Придворной конюшенной части: вероятно, в связи с военизированной структурой этого учреждения, куда на руководящие должности назначались офицеры-кавалеристы, в него перешел и ряд армейских порядков, вылившихся в 1917 г. в противостояние между солдатами и офицерами. 13 апреля общее собрание служащих конюшенного ведомства постановило обратиться в Исполком Петроградского совета с рядом предложений, касавшихся улучшения их материального положения (ставились вопросы о восьмичасовом рабочем дне, повышении жалованья и т. д.) [28, л. 3]. Примерно тогда же, в конце марта - начале мая ${ }^{2}$ общее собрание под председательством младшего шорного кучера Л.И. Полищука [15, л. 99 об.] обратилось к уполномоченному Дзюбинскому, требуя «отстронить от занимаемых ими должнастей, как не пользующихся доверием служащих $)^{3}$ восьмерых начальствующих лиц (А.Х. Палео- лога, Б.В. Литвинова, А.А. Зееста, В.А. Измайлова, П.А. Обермиллера, А.А. Мосолова, А.А. Коржавина, В.Г. Жданова) [28, л. 4]. Отметим, что это требование далеко не полностью было удовлетворено новыми властями: Палеолог (с 4 мая), Зеест и Коржавин (с 1 июня) действительно были уволены (официально - по собственному прошению), тогда как Литвинов и Измайлов не только остались на службе, но и получили в течение 1917 г. повышения [26, л. 48 об., 91 об., 116]. 21 мая низшие служащие на очередном собрании под руководством упомянутого председателя «Комитета выборных» Л.И. Полищука выработали свои пожелания, связанные с возможной ликвидацией или радикальным преобразованием установления: они просили руководство в этом случае «ускорить выдачу судосберегательной и вспомогательной кассы», «не предъявлять служащим немедленно очищать казенные квартиры ими занимаемые» и распределить между служащими взятое из интендантства сукно «для постройки летнего платья» по цене, уплаченной интендантству. Старшие служащие ведомства также задумывались в это время о его будущем: в архивном фонде Придворной конюшенной части среди бумаг апреля - мая 1917 г. сохранились два недатированных и неподписанных печатных листа, озаглавленных как «Вопросы, требующие разрешения». В списке вопросов значились: судьба Конюшенного музея и вещей, «составляющих личную собственность Их Величеств и Государя Наследника», предложение о возможной продаже царских лошадей с аукциона, пожелание об оставлении «до ликвидации или переформирования Части всем служащим полного установленного содержания и довольствия» [2, л. 9-10, 12].

Дзюбинский, по своим интересам далекий от кавалерийских проблем, недолго пробыл уполномоченным по бывшей Придворной конюшенной части. Приказом Ф.А. Головина от 26 апреля заместителем Дзюбинского был назначен Евгений Александрович Френкель, с 1 мая официально ставший уполномоченным ${ }^{4}$ с окладом 600 руб. в месяц [16, л. 11; 25 , с. $2 ; 26$, л. 37,73$]$. Так же как и оба его предшественника на этом посту, Френкель отнюдь не являлся опытным лошадником. $\mathrm{B}$ «Коллекции автобиографий русских писателей и ученых», собранной С.А. Венгеровым и 
отложившейся в его фонде в Рукописном отделе Пушкинского дома, сохранилась заполненная Френкелем в 1919 г. анкета, позволяющая установить основные вехи биографии: родился в Киеве в 1881 г., православный, родители - «купеческого состояния», образование получал «в Одессе и заграницей», основное занятие - «литератор и преподаватель средн[их] учебн[ых] зав[едений]». Писал под псевдонимом Е. Адамов в целом ряде журналов и газет, в том числе в «Киевской мысли», «Русском слове», «Русских ведомостях», «Речи», «Дне»; основными темами его публицистики были «Иностран[ная] жизнь, литература, обществ[енная] жизнь. "Письма" из Германии, Франции, Испании, Турции еtс. Московские и Петроградские». Графу «Особенно замечательные события жизни» Френкель заполнил так: «Начал писать в киевск[их] изд[аниях] в 1898 г. В народ пошел (земск[им] учит[елем]) в 1901 г. Сотрудник толстых журн[алов] с 1902 г. Админ[истративная] ссылка в Нарым [в] 1906 г., заграницу [в] 1907 году. Возвращение в Россию в 1911 году. При Врем[енном] Правит[ельстве] - уполномоченный К[омисса]ра В[ременного] П[равительства]» $[37$, л. 1]. Жизненный путь Е.А. Френкеля представляется вполне типичным на фоне многочисленных похожих биографий российских оппозиционных публицистов, но, конечно, довольно нестандартным для руководителя конюшенного ведомства. Возможно, причина его назначения заключалась в принадлежности Френкеля к трудовикам, на что имеется указание в составленном в 1918 г. «Отчете о политической деятельности Автомобильной Базы Рабочего и Крестьянского Правительства» (см. ниже), - в этом случае он мог быть рекомендован своим однопартийцем В.И. Дзюбинским. Так или иначе, журналисту, специализировавшемуся на очерках из иностранной жизни, трудно было завоевать авторитет как у начальствующего состава, так и у низших служащих вверенного ему, но вряд ли сколько-нибудь знакомого ведомства.

Поскольку Е.А. Френкель по возрасту подлежал призыву в войска, Ф.А. Головин дважды (31 мая и в июле) обращался по этому вопросу к А.Ф. Керенскому. Указав во втором из этих обращений, что «Френкель занимает, собственно, должность положенную в
III классе и тем самым, согласно Уставу о воинской повинности, подлежал бы по сей должности освобождению от военной службы», Головин пояснял: «Хотя ратник 2 разряда Френкель не был назначен Управляющим бывшею Придворною Конюшенною Частью, а состоялся приказ о назначении его Уполномоченным по делам сей части, то подобное оформление замещения вакантной должности Управляющего было осуществлено по тем соображениям, что в переживаемое время являлось затруднительным заместить должность Начальника установления бывшего Министерства Двора которое предполагается в будущем к упразднению или реорганизации» [21, л. 81-85 об.]. Впрочем, пока что видимая обществу «реорганизация» конюшенной части выражалась в распродаже с аукциона части «царских» лошадей и экипажей $[29$, с. 2].

С 8 мая Е.А. Френкель начал, в качестве уполномоченного, подписывать приказы по «бывшей Придворной Конюшенной Части». С 8 августа формулировка изменилась: теперь приказы отдавались «бывшей Придворной Конюшенной Части и бывшему Собственному Его Величества Гаражу» [27, л. 15-16, 30]. За этим стояла определенная работа по «интеграции» Гаража в конюшенное ведомство, проводившаяся (вопреки предложениям Купчинского) руководством Комиссариата. Так, 16 июня Френкель получил служебное письмо из Хозяйственного отдела Кабинета, в котором «за последовавшей передачей б. Собственного Е. В. Гаража в Ваше ведение» предполагалось «в целях упрощения и ускорения делопроизводства по выдачам и уплатам по б. Гаражу, производимым ныне по ассигновкам б. Кабинета Его Величества, передать производство упомянутых выдач и уплат Вашему ведению непосредственно». По приказанию Головина отдел «предварительно утверждения этого предположения» запрашивал мнение Френкеля по изложенному вопросу. Уполномоченный ответил 22 июня, что «передача делопроизводства <...> в ведение б. Собственного Его Величества Гаража желательна, но что осуществить это предположение возможно не ранее начала будущего года, при ассигновании кредитов сметы б. Гаража и окончания подготовительных работ, мною предпринятых в настоящее время по делопроизводству и эксплуата- 
ции б. Придворной Конюшенной Части и б. Гаража в целях полного объединения их деятельности» [13, л. 2-3].

Устройство Гаража требовало постоянного внимания уполномоченного - как по неопределенности его бюджетного положения, так и по тому, что еще 27 марта, при Купчинском, инспектор Гаража Д.В. Ден подал заявление об отставке, удовлетворенное Ф.А. Головиным (о чем вр. и. о. начальника Канцелярии бывшего МИДв С.В. Гагарин сообщил Дену 5 апреля). Спустя несколько месяцев, 16 августа, Е.А. Френкель попытался найти себе помощника по автомобильной части, обратившись к Головину с предложением «зачислить на службу в бывший Собственный Его Величества Гараж Потомственного Дворянина Николая Ивановича Величко - Заведывающим хозяйственною частью Гаража с 1-го Июня сего года, с временным окладом в 3600 рублей в год». Комиссар поручил изучить этот вопрос Канцелярии бывшего МИДв, служащий которой, известный деятель «Мира искусства» В.Ф. Нувель составил к 24 августа справку, где отмечал, что «штатов Гаража не утверждено и что поэтому штатной должности Заведывающего Хозяйственною Частью с окладом содержания в сем установлении не имеется». Тем не менее, учитывая, возможно, желание Головина пойти навстречу своему уполномоченному, Нувель предложил «сообщить Г. Френкелю, что к осуществлению предположения его о назначении Величко Заведывающим Хозяйственною Частью сего установления, с производством содержания по 3600 руб. из свободных сумм Гаража, со стороны Г. Комиссара препятствий не встречается». В этом духе и было составлено отношение Канцелярии бывшего МИДв к Е.А. Френкелю 28 августа. Однако, когда 15 сентября последний вновь обратился к комиссару с предложением назначить исполняющему обязанности заведующего хозяйственной частью бывшего Гаража Его Величества Н.И. Величко еще и квартирные деньги в размере 1000 руб., заведующий Временной комиссией для ликвидации Контролей б. Министерства двора и уделов Д.П. Богданов, к которому на отзыв было отправлено ходатайство Френкеля, ответил (10 ок- тября), что руководимая им комиссия «затрудняется сообщением отзыва по ходатайству о назначении г. Величко квартирных денег по VI классу, тем более что не только никаких сумм по смете Гаража не имеется, но предстоит весьма крупная передержка». В итоге уже в конце ноября вр. и. о. комиссара над бывшим МИДв Н.Э. Рюдман отклонил предложение о выплате Величко квартирных денег [18, л. 62, 64, 892-896, 898].

Некоторые штрихи «френкелевского» периода истории конюшенного ведомства содержатся в уже упоминавшемся дневнике С.И. Смирновой-Сазоновой, интересовавшейся служебным положением своего родственника А.В. Давыдова. Со свойственной ей прямотой писательница, державшаяся правых взглядов, зафиксировала 13 сентября: «У Давыдова давно уже б[ыли] нелады с его начальством, жидом Френкелем. Марья Николаевна, желая помочь сыну, оказала ему медвеж[ью] услугу. Она написала Стаховичу ${ }^{5}$, их бывш[ему] орловск[ому] предводителю, что положение Давыдова невыносимо, что в конюшен[ном] ведомстве хозяйничают жиды, что Френкель выдвигает только своих, и просила куда-ниб[удь] устроить Давыдова. Стахович, кот[орый] в это время сам бросил финлянд[ское] ген[ерал]-губернаторство и кот[орому] б[ыло] не до того, чт[обы] устраивать других, переслал это письмо Головину, а тот, не долго думая, послал его тому же Френкелю. Как верн[ый] жидовск[ий] слуга, он выдает жидам русских, кот[орые] осмеливаются их хулить. Можно судить, в как[ое] положение попал теперь Давыдов». 17 сентября Давыдов, рассказывая Смирновой-Сазоновой о своих служебных делах, сообщил, что «они т[ак] плохи, что не нынче-завтра из конюшен[ного] ведомства ему придется уйти. На его место уже приглашен какой-то полковник. Френкель невзлюбил его за глухоту и за то, что он недостаточно расторопен, не умел, напр[имер], найти сена, а какой-то др[угой] служащий поехал и достал полтораста пудов. Письмо Марии Николаевны, кот[орое] Головин переслал Френкелю, испортило окончательно отношения последнего с Давыдовым» [34, л. 375-376, 379-380]. Впрочем, «барин старого закала», как называла Давыдова Смирнова-Сазонова, смог пережить и этого 
начальника, подобно промелькнувшим до него на административном небосклоне Ф.П. Купчинскому и В.И. Дзюбинскому.

11 сентября и. д. смотрителя зданий бывшей Придворной конюшенной части ротмистр А.А. Мосолов доложил Е.А. Френкелю о проникновении воров в Конюшенный музей, что обнаружилось при осмотре музея в этот день в связи с проведением работ «по укладке музейного имущества». Грабителям пришлось потрудиться, чтобы попасть в здание («осмотр помещения показал, что на чердаке здания Музея крыша взломлена, а каменная стена корпуса № 2, соприкасающаяся с Музеем, была проломлена около аршина шириной»), где им удалось поживиться рядом ценных вещей. Согласно рапорту Мосолова, все хищения были совершены в музейном зале № 4: «1) не хватает на наружной стороне левой дверцы кареты за № 16 - трех аметистов, 126 тяжеловесов и 2 красных камня; 2) на 8-местной карете за № 17 на передней части левой стороны сорвано бронзовое украшение, которое было найдено в том же зале; 3) на золоченой карете за № 12 сорвана бронзовая корона и с плата бронзовое вензелевое украшение, которое также было найдено в том же зале» [31, л. 61-61 об.]. Эти тревожные известия могли лишь усилить общее нервное настроение служащих, квартиры которых располагались в соседних с музеем зданиях, и увеличить их подозрительность по отношению друг к другу: кража в подобном, весьма специализированном по характеру своих коллекций, учреждении невольно заставляла думать о соучастии в ней кого-то из работников конюшенной части.

24 октября, согласно записи СмирновойСазоновой, «везде запирают наглухо ворота и подъезды. В конюшен[ном] ведомстве у всех ворот поставили казаков» [34, л. 458-459], Френкель, подписав свой последний приказ по ведомству [27, л. 47-47 об.], отправился на заседание Совещания по пересмотру штатов бывшего МИДв. Там был принят ряд важных решений о дальнейшей судьбе руководимого им установления (несмотря на сомнения собравшихся в том, что оно сохранится в будущем в составе Комиссариата), которое в соответствии с предложением Ф.А. Головина, внесенным на рассмотрение кабинета мини- стров, постановили переименовать в «Автомобильную и конюшенную базу Временного правительства». Члены Совещания одобрили предложенные Френкелем меры по сокращению штатов конюшенной части и более тесному ее объединению с бывшим Гаражом, носившим теперь название «Автомобильной части Базы» [8, л. 7-8]. Тем временем назревали события, которые радикальным образом скорректировали намеченный уполномоченным путь преобразований - именно ему, как ставленнику свергнутого правительства, в первую очередь и пришлось «сократиться».

5 августа 1918 г. Комитетом служащих некогда возглавляемого Френкелем установления был составлен «Отчет о политической деятельности Автомобильной Базы Рабочего и Крестьянского Правительства», в котором кратко была обрисована сложившаяся накануне штурма Зимнего ситуация: «С первых дней Февральской Революции вся власть по Управлению Автомобильной Базой бывш. Временного Правительства перешла всецело в руки назначенных от б. Правительства уполномоченных, из коих последнее время перед Октябрьским переворотом был трудовик Френкель, и в то время существовал Комитет служащих, куда и вошли 2 партийных члена: большевик и эс-эр, который ведал только чисто профессиональным вопросом и всегда жил враждебно с Уполномоченным Френкелем и его ставленником Заведующим Хозяйственной Частью Величко». С 26 октября, говорилось далее в отчете, «т. е. с первого дня Социальной Революции, вся власть по Управлению Автомобильной Базой перешла целиком в руки Комитета, что и видно из протокола от 27 Октября 1917 г. за № 15 - где говорится, что всем служащим предлагается беспрекословно подчиняться распоряжениям Комитета. Того же числа Комитет немедленно делегировал в Смольный к Тов. Луначарскому депутацию с резолюцией, вынесенной на Общем Собрании служащих, что Автомобильная База признает власть Советов и отдает в полное распоряжение Военно-Революционного Комитета все имеющиеся автомобили и этим самым дала она ускорение действий Нового Правительства». Вскоре база была подчинена назначенному большевиками комендантом Зимнего дворца корнету Н.И. Покровскому 
(в «Отчете» назначение последнего «комиссаром» базы отнесено к 28 октября, отношение ВРК к коллективу базы с известием об этом датировано 29 октября). Впрочем, как отмечалось в «Отчете», Покровский пробыл «на означенном посту около недели и по неизвестным для нас причинам он был удален» [19, л. 2; 22, с. 309].

Отметим, что в эти дни, на волне Октябрьской революции, чуть было не вернулся в конюшенное ведомство Ф.П. Купчинский. Еще в советское время среди документов, отложившихся в фонде Петроградского ВРК, был опубликован весьма примечательный приказ наркома просвещения А.В. Луначарского (которому новая власть поручила заведывание и бывшим МИДв) от 5 ноября 1917 года. Луначарский, «на основании постановлений общего собрания служащих автомобильно-конюшенной базы Российской республики от 5 ноября 1917 г.» объявлял в приказе об увольнении ряда начальствующих лиц Придворной конюшенной части и назначении на их место кандидатов, угодных общему собранию служащих. Наиболее важная часть документа касалась главы установления Е.А. Френкеля, которого предписывалось «освободить от занимаемой им должности $<$... > и на место его утверждаю избранного служащими Ф.П. Купчинского, в должности уполномоченного, коему, как лицу, облеченному доверием служащих базы, Е.А. Френкель обязан немедленно сдать свою должность». В том же документе содержалось требование и к Н.И. Величко сдать дела «Ф.И. Гензелю, выбранному служащими на должность заведующего автомобильной частью, от комитета служащих» [23, с. 140].

Однако вопреки приказу наркома просвещения Купчинский во главе базы так и не стал. Он даже не упоминается в «Отчете о политической деятельности Автомобильной Базы Рабочего и Крестьянского Правительства», где указано, что 5 ноября, в день издания приказа, на общем собрании служащих в присутствии Луначарского был избран «на место непризнанного служащими Уполномоченного Френкеля» подполковник Александр Густавович Болин [19, л. 2-2 об.], получивший полномочия и от руководства Комиссариата - приказом врио комиссара Временного правительства над бывшим МИДв Н.Э. Рюдмана - от
20 ноября ему было поручено временное исполнение обязанностей уполномоченного по делам бывшей Придворной Конюшенной Части и бывшего Гаража Его Величества ввиду «отъезда из Петрограда» Е.А. Френкеля [26, л. 135]. Причиной, помешавшей Купчинскому вернуться к руководству Автоконюшенной базой могло стать его резкое идейное расхождение с большевистскими властями, проявившееся вскоре после Октябрьской революции и приведшее в конце концов Купчинского в стан противников большевиков в Гражданской войне [7, с. 78-79]. Что же касается Болина, то можно констатировать, что впервые со времен Февральской революции во главе конюшенного ведомства встал профессионал-кавалерист, имевший за своими плечами десятилетний опыт службы в этом установлении [35, с. 313], продолжавший, впрочем, до самого конца года подписывать приказы по части как «заместитель уполномоченного Комиссара Временного Правительства» [27, л. 48-55 об.]. Болин и в самом деле не был полновластным начальником ведомства - в качестве политического руководителя «10-го Декабря Центральным Исполнительным Комитетом был назначен и утвержден Тов. Луначарским в должности Комиссара Авто-Конюшенной Базы Товарищ Бородачев» [19, л. 2 об.]. В 1918 г. комиссар И. Бородачев уже «утверждал» приказы по базе, подписывавшиеся к тому времени председателем коллектива служащих [10, л. 7-9].

Изложив, таким образом, фактическую сторону деятельности бывших Придворной конюшенной части и Гаража Его Величества в 1917 г., представляется возможным сделать некоторые выводы. Во-первых, характерной чертой их истории в это время явилась частая смена начальников, которых в течение года было семь человек (А.А. Гринвальд, Ф.П. Купчинский, В.И. Дзюбинский, Е.А. Френкель, Н.И. Покровский, А.Г. Болин, И. Бородачев), причем только двое (Гринвальд и Болин) могли считаться специалистами в порученном их ведению деле. Во-вторых, низшие служащие этих установлений отличались, на фоне прочих работников бывшего придворного ведомства, сравнительным радикализмом и достаточно большой степенью организованности, выдвигая к руководству требования как 
экономического, так и чисто административного характера (об увольнении неугодных им чиновников ведомства). В-третьих, дискуссионным вопросом оставался статус Гаража: если Купчинский предлагал выделить его из состава конюшенной части, то Френкель, наоборот, предпринимал усилия по объединению их деятельности. Наконец, в четвертых, следует отметить то непростое положение, в котором оказались старшие служащие, с одной стороны, теснимые кучерами и конюхами, а с другой - не всегда находившие понимание у случайных, в общем, лиц, возглавлявших в 1917 г. конюшенное ведомство.

\section{ПРИМЕЧАНИЯ}

${ }^{1}$ Имеется в виду служивший ранее в Придворной конюшенной части полковник А.Г. Штауф [3, c. 746].

2 Документ не датирован. Примерная датировка дается на основании того, что адресат, В.И. Дзюбинский, состоял уполномоченным по бывшей Придворной конюшенной части с 30 марта, а упоминаемый в тексте А.Х. Палеолог был уволен в отставку 4 мая [14, л. 12].

3 Здесь и далее сохранена орфография и пунктуация оригинала.

4 Впрочем, некоторое время продолжалось «двоевластие»: уже в июне Дзюбинскому, по представлению Френкеля, была назначена 1000 руб. (та же сумма, что и Купчинскому) в вознаграждение «за труды по Заведыванию бывшей Придворной Конюшенной Части, с 30 Марта по 15 Мая сего года»; в другой канцелярской справке указывалось, что Дзюбинский продолжал заниматься делами установления до 13 мая [16, л. 5; 18, л. 462].

${ }^{5}$ Имеется в видуМ.А. Стахович [36, с. 587-588].

\section{СПИСОК ЛИТЕРАТУРЫ}

1. Агеева, О. Г. Императорский двор России, 1700-1796 годы/ О. Г. Агеева. - М. : Наука, 2008. - 379 с.

2. Бумаги, касающиеся ликвидации быв. Придворной конюшенной части // Российский государственный исторический архив (РГИА). - Ф. 477.Оп. 11.-Д. 672.

3. Весь Петроград: Адресная и справочная книга гор. Петрограда на 1915 год. - Пг. : Т-во А.С. Суворина «Новое время», 1915. - Отд. III. - С. 1-777.

4. Весь Петроград: Адресная и справочная книга гор. Петрограда на 1917 год. - Пг. : Т-во А.С. Суворина «Новое время», 1917. - Отд. І. - С. 1-1596.
5. Главный гараж России: от собственного Его Императорского Величества гаража до Гаража особого назначения, 1907-2007. - М. : МедиаПресс, 2007. $-233 \mathrm{c}$.

6. Гордеев, П. Н. Февральская революция и Министерство двора / П. Н. Гордеев // Революция 1917 года в России: новые подходы и взгляды. -СПб. : ЭлекСис, 2011.- С. 21-58.

7. Гордеев, П. Н. Ф.П. Купчинский - уполномоченный Временного комитета Государственной думы и Временного правительства по делам бывшей Придворной конюшенной части и бывшего Гаража его величества / П. Н. Гордеев // Таврические чтения-2012. Актуальные проблемы парламентаризма: история и современность. - СПб. : ЭлекСис, 2013. - Ч. 2. - С. 48-79.

8. Журналы заседаний совещания по пересмотру штатов б. Министерства имп. двора // РГИА. Ф. 482. - Оп. 10. - Д. 1337.

9. Зимин, И. В. Повседневная жизнь Российского императорского двора. Вторая четверть XIX начало XX в. Взрослый мир императорских резиденций / И. В. Зимин. - М. : Центрполиграф, 2010. $556 \mathrm{c}$.

10. Копии приказов по Петербургскому отделению авто-конюшенной базы рабочего и крестьянского правительства // Центральный государственный архив литературы и искусства Санкт-Петербурга. - Ф. 29. - Оп. 1. - Д. 13.

11. Любарская, Т. Г. Министерство императорского двора и его учреждения / Т. Г. Любарская // Высшие и центральные государственные учреждения России, 1801-1917. В 4 т. Т. 3. - СПб. : Наука, 2002. - С. 145-188.

12. Николаев, А. Б. Дзюбинский Владимир Иванович / А. Б. Николаев // Государственная дума Российской империи: 1906-1917 : Энциклопедия. -М. : РОССПЭН, 2008. - С. 163-164.

13. Об объединении быв. гаража императора с быв. Придворной конюшенной частью // РГИА. Ф. 477. - Оп. 11. - Д. 670.

14. Об увольнении от службы по болезни управляющего канцелярией генерал-лейтенанта Палеолога и о назначении ему пенсии // РГИА. Ф. 477. - Оп. 11.- Д. 674.

15. О жалобах служащих, рассмотренных Особой комиссией об обидах и материальном ущербе, причиненных им прежним управлением // РГИА. Ф. 477. - Оп. 11. - Д. 677.

16. О назначении комиссаром временного правительства над быв. Придворной конюшенной частью члена Госуд. Думы В.И. Дзюбинского и уполномоченным комиссара временного правительства над быв. министерством двора по делам быв. Придворной конюшенной части Е.А. Френкеля // РГИА. Ф. 477.-Оп. 11.-Д. 680. 
17. О переменах в личном составе бывшего Министерства Двора // РГИА. - Ф. 472. - Оп. 58 (15 доп.). - Д. 2.

18. О переменах в личном составе бывшего Министерства Двора // РГИА. - Ф. 472. - Оп. 58 (15 доп.). - Д. 3 а.

19. Отчеты о деятельности Комиссариата имуществ Республики, Петроградского отделения Комиссариата и автомобильной базы Рабочего и Крестьянского правительства // Государственный архив Российской Федерации. - Ф. Р-410. - Оп. 1. - Д. 23.

20. О финансовой смете Придворной конюшенной части на 1917 г. // РГИА. - Ф. 477. - Оп. 11. - Д. 681.

21. Переписка с учреждениями М. Имп. Дв. и начальником мобилизационного отдела Главного управления Генерального штаба о предоставлении отсрочки от призыва служащим М. И. Дв., с приложением списков // РГИА. - Ф. 472. - Оп. 66. - Д. 595.

22. Петроградский Военно-революционный комитет. Документы и материалы. В 3 т. Т. 1. - М. : Наука, 1966. - 584 с.

23. Петроградский Военно-революционный комитет. Документы и материалы. В 3 т. Т. 2. - М. : Наука, 1966. - 558 с.

24. Приказы и телеграммы о назначении комиссаров Временного комитета Гос. думы для организации власти и подавления забастовочного движения в городах Сестрорецке, Ревеле, на Кавказе и др. // РГИА. - Ф. 1278. - Оп. 10. - Д. 7.

25. Приказы комиссара Временного Правительства над бывшим министерством двора // Вестник Временного правительства. - 1917. - 13 июня.

26. Приказы Комиссара Временного Правительства по ведомству бывшего Министерства Двора и Уделов // РГИА. - Ф. 472. - Оп. 58 (15 доп.). - Д. 1.

27. Приказы по Придворной конюшенной части // РГИА. - Ф. 477. - Оп. 11. - Д. 166.

28. Протоколы собраний служащих авто-базы Временного правительства и Гос. Думы. Копии // РГИА. - Ф. 477. - Оп. 11. - Д. 1417.

29. Разные известия // Новое время. - 1917. 1 июля.

30. Разные предметы // РГИА. - Ф. 500. Оп. 1. - Д. 822.

31. С донесениями о происшествиях по Мин. имп. двора // РГИА. - Ф. 472. - Оп. 48. - Д. 716.

32. Смета доходов и расходов Министерства императорского двора на 1917 г. // РГИА. - Ф. 468. Оп. 17.- Д. 2459.

33. Смирнова-Сазонова, С. И. Дневник за 1917 г. / С. И. Смирнова-Сазонова // Рукописный отдел Института русской литературы РАН (РО ИРЛИ). Ф. 285. - № 65 .

34. Смирнова-Сазонова, С. И. Дневник за 1917 г. / С. И. Смирнова-Сазонова // РО ИРЛИ. - Ф. 285. № 66 .
35. Список чинов Министерства Императорского Двора. 5 Сентября 1910 года. - СПб. : Т-во Р. Голике и А. Вильборг, 1910. - 785 с.

36. Стахович Михаил Александрович // Государственная дума Российской империи: 1906-1917 : Энциклопедия. - М. : РОССПЭН, 2008. - С. 587-588.

37. Френкель, Е. А. Анкета с ответами на вопросы КБС / Е. А. Френкель // РО ИРЛИ. -Ф. 377. Оп. 7. - № 3732 .

38. Хроника // Биржевые ведомости (вечерний выпуск). - 1917. - 16 марта.

\section{REFERENCES}

1. Ageeva O.G. Imperatorskiy dvor Rossii, 1700-1796 gody [The Imperial Court of Russia, 17001796]. Moscow, Nauka Publ., 2008. 379 p.

2. Bumagi, kasayushchiesya likvidatsii byv. Pridvornoy konyushennoy chasti [Papers Relating to the Elimination of the Former Court Stable Department]. Rossiyskiy gosudarstvennyy istoricheskiy arkhiv [Russian State Historical Archive], F. 477, Op. 11, D. 672.

3. Ves Petrograd: Adresnaya i spravochnaya kniga gor. Petrograda na 1915 god [Whole Petrograd: Address and Reference Book of Petrograd in 1915]. Petrograd, T-vo A.S. Suvorina «Novoe vremya» Publ., 1915, Part III, pp. 1-777.

4. Ves Petrograd: Adresnaya i spravochnaya kniga gor. Petrograda na 1917 god [Whole Petrograd: Address and Reference Book of Petrograd in 1917]. Petrograd, T-vo A.S. Suvorina «Novoe vremya» Publ., 1917, Part I, pp. 1-1596.

5. Glavnyy garazh Rossii: ot sobstvennogo Ego Imperatorskogo Velichestva garazha do Garazha osobogo naznacheniya, 1907-2007 [The Main Garage of Russia: from His Imperial Majesty's Garage to the Garage of the Special Purpose, 1907-2007]. Moscow, MediaPress Publ., 2007. 233 p.

6. Gordeev P.N. Fevralskaya revolyutsiya i Ministerstvo dvora [The February Revolution and the Ministry of the Court]. Revolyutsiya 1917 goda $v$ Rossii: novye podkhody i vzglyady [The Revolution of 1917 in Russia: New Approaches and Views]. Saint Petersburg, ElekSis Publ., 2011, pp. 21-58.

7. Gordeev P.N. F.P. Kupchinskiy upolnomochennyy Vremennogo komiteta Gosudarstvennoy dumy i Vremennogo pravitelstva po delam byvshey Pridvornoy konyushennoy chasti i byvshego Garazha ego velichestva [F.P. KupchinskyRepresentative of the Provisional Committee of the State Duma and Provisional Government for the Affairs of the Former Court Stable Department and the Former Garage of His Majesty]. Tavricheskie chteniya 2012. Aktualnye problemy parlamentarizma: istoriya $i$ 
sovremennost [Tauric Readings in 2012. Current Problems of Parliamentarism: History and Modernity]. Saint Petersburg, ElekSis Publ., 2013, Part 2, pp. 48-79.

8. Zhurnaly zasedaniy soveshchaniya po peresmotru shtatov b. Ministerstva imp. dvora [The Journals of the Sessions of the Counsel on the Revision of the States of Former Ministry of Imperial Court]. Rossiyskiy gosudarstvennyy istoricheskiy arkhiv [Russian State Historical Archive], F. 482, Op. 10, D. 1337.

9. Zimin I.V. Povsednevnaya zhizn Rossiyskogo imperatorskogo dvora. Vtoraya chetvert XIX nachalo $X X v$. Vzroslyy mir imperatorskikh rezidentsiy [Daily Life of the Russian Imperial Court. Second Quarter of the $19^{\text {th }}-$ Beginning of the $20^{\text {th }}$ Century. The Adult World of the Imperial Residences]. Moscow, Tsentrpoligraf Publ., 2010. $556 \mathrm{p}$.

10. Kopii prikazov po Peterburgskomu otdeleniyu avto-konyushennoy bazy rabochego i krestyanskogo pravitelstva [Copies of the Orders of the St. Petersburg Office of a Car-Stables Base of Worker and Peasant Government]. Tsentralnyy gosudarstvennyy arkhiv literatury $i$ iskusstva SanktPeterburga [Central State Archive of Literature and Art of St. Petersburg], F. 29, Op. 1, D. 13.

11. Lyubarskaya T.G. Ministerstvo imperatorskogo dvora i ego uchrezhdeniya [The Ministry of the Imperial Court and Its Institutions]. Vysshie $i$ tsentralnye gosudarstvennye uchrezhdeniya Rossii, 1801-1917. V 4 t. T. 3 [The Superior and the Central State Institutions of Russia. 1801-1917. In 4 vols. Vol. 3]. Saint Petersburg, Nauka Publ., 2002, pp. 145-188.

12. NikolaevA.B. Dzyubinskiy Vladimir Ivanovich [Vladimir Ivanovich Dziubinsky]. Gosudarstvennaya duma Rossiyskoy imperii, 1906-1917: Entsiklopediya [The State Duma of the Russian Empire, 1906-1917: Encyclopedia]. Moscow, Rossiyskaya politicheskaya entsiklopediya Publ., 2008, pp. 163-164.

13. Ob obyedinenii byv. garazha imperatora $\mathrm{s}$ byv. Pridvornoy konyushennoy chastyu [About the Association of the Former Emperor's Garage with the Former Court Stable Department]. Rossiyskiy gosudarstvennyy istoricheskiy arkhiv [Russian State Historical Archive], F. 477, Op. 11, D. 670.

14. Ob uvolnenii ot sluzhby po bolezni upravlyayushchego kantselyariey general-leytenanta Paleologa i o naznachenii emu pensii [About Dismissal from the Service due to Illness of the Manager of the Office of Lieutenant-General Paleolog and on the Granting of Pension]. Rossiyskiy gosudarstvennyy istoricheskiy arkhiv [Russian State Historical Archive], F. 477, Op. 11, D. 674.

15. O zhalobakh sluzhashchikh, rassmotrennykh Osoboy komissiey ob obidakh i materialnom ushcherbe, prichinennykh im prezhnim upravleniem [On Complaints of Employees Considered by the
Special Commission of the Offense and the Material Damage Caused to Them by the Previous Management]. Rossiyskiy gosudarstvennyy istoricheskiy arkhiv [Russian State Historical Archive], F. 477, Op. 11, D. 677.

16. O naznachenii komissarom vremennogo pravitelstva nad byv. Pridvornoy konyushennoy chastyu chlena Gosud. Dumy V.I. Dzyubinskogo i upolnomochennym komissara vremennogo pravitelstva nad byv. ministerstvom dvora po delam byv. Pridvornoy konyushennoy chasti E.A. Frenkelya [On the Appointment of the Commissioner of the Provisional Government over the Former Court Stable Department by Member of the State Duma V.I. Dzyubinsky and Representative of the Commissioner of the Provisional Government over the former Ministry of the Court to the Affairs of the Former Court Stable Department E.A. Frenkel]. Rossiyskiy gosudarstvennyy istoricheskiy arkhiv [Russian State Historical Archive], F. 477, Op. 11, D. 680.

17. O peremenakh v lichnom sostave byvshego Ministerstva Dvora [Changes in Staff of the Former Ministry of the Court]. Rossiyskiy gosudarstvennyy istoricheskiy arkhiv [Russian State Historical Archive], F. 472, Op. 58 (15 dop.), D. 2.

18. O peremenakh $\mathrm{v}$ lichnom sostave byvshego Ministerstva Dvora [Changes in Staff of the Former Ministry of the Court]. Rossiyskiy gosudarstvennyy istoricheskiy arkhiv [Russian State Historical Archive], F. 472, Op. 58 (15 dop.), D. 3a.

19. Otchety o deyatelnosti Komissariata imushchestv Respubliki, Petrogradskogo otdeleniya Komissariata i avtomobilnoy bazy Rabochego i Krestyanskogo pravitelstva [Reports on the Activity of the Commissariat of the Republic's Possessions, the Petrograd Branch of the Commissariat and Auto Base of the Worker and Peasant Government]. Gosudarstvennyy arkhiv Rossiyskoy Federatsii [State Archive of the Russian Federation], F. R-410, Op. 1, D. 23.

20. O finansovoy smete Pridvornoy konyushennoy chasti na 1917 g. [On the Financial Framework of the Court Stable Department for 1917]. Rossiyskiy gosudarstvennyy istoricheskiy arkhiv [Russian State Historical Archive], F. 477, Op. 11, D. 681.

21. Perepiska s uchrezhdeniyami M. Imp. Dv. i nachalnikom mobilizatsionnogo otdela Glavnogo upravleniya Generalnogo shtaba o predostavlenii otsrochki ot prizyva sluzhashchim M. I. Dv., s prilozheniem spiskov [Correspondence with Institutions of the Ministry of the Imperial Court and Head of the Mobilization Department of the Main Directorate of the General Staff on Granting a Deferment to the Employees of the Ministry of the Imperial Court with the Application of List]. Rossiyskiy gosudarstvennyy istoricheskiy arkhiv [Russian State Historical Archive], F. 472, Op. 66, D. 595. 
22. Petrogradskiy Voenno-revolyutsionnyy komitet. Dokumenty i materialy. V 3 t. T. 1 [The Petrograd Military Revolutionary Committee. Documents and Materials. In 3 vols. Vol. 1]. Moscow, Nauka Publ., 1966. 584 p.

23. Petrogradskiy Voenno-revolyutsionnyy komitet. Dokumenty i materialy. V 3 t. T. 2 [The Petrograd Military Revolutionary Committee. Documents and Materials. In 3 vols. Vol. 2]. Moscow, Nauka Publ., 1966. 558 p.

24. Prikazy i telegrammy o naznachenii komissarov Vremennogo komiteta Gos. dumy dlya organizatsii vlasti i podavleniya zabastovochnogo dvizheniya v gorodakh Sestroretske, Revele, na Kavkaze $\mathrm{i}$ dr. [Orders and Telegrams on the Appointment of the Commissioners of the Provisional Committee of the State Duma for the Organization of Power and the Suppression of Strike Movement in the Towns of Sestroretsk, Revel, in the Caucasus etc.]. Rossiyskiy gosudarstvennyy istoricheskiy arkhiv [Russian State Historical Archive], F. 1278, Op. 10, D. 7.

25. Prikazy komissara Vremennogo Pravitelstva nad byvshim ministerstvom dvora [The Orders of the Commissioner of the Provisional Government of the Former Ministry of the Court]. Vestnik Vremennogo pravitelstva [Bulletin of the Provisional Government], 13 June 1917.

26. Prikazy Komissara Vremennogo Pravitelstva po vedomstvu byvshego Ministerstva Dvora i Udelov [The Orders of the Commissioner of the Provisional Government in the Department of the Former Ministry of Court and Appanages]. Rossiyskiy gosudarstvennyy istoricheskiy arkhiv [Russian State Historical Archive], F. 472, Op. 58 (15 dop.), D. 1.

27. Prikazy po Pridvornoy konyushennoy chasti [The Orders of the Court Stable Department]. Rossiyskiy gosudarstvennyy istoricheskiy arkhiv [Russian State Historical Archive], F. 477, Op. 11, D. 166.

28. Protokoly sobraniy sluzhashchikh avto-bazy Vremennogo pravitelstva i Gos. Dumy. Kopii [Minutes of Meetings of Employees of Auto-Base of the Provisional Government and the State Duma. Copies]. Rossiyskiy gosudarstvennyy istoricheskiy arkhiv [Russian State Historical Archive], F. 477, Op. 11, D. 1417.

29. Raznye izvestiya [Different News]. Novoe vremya [The New Time], 1917, 1 July.

30. Raznye predmety [Different Objects]. Rossiyskiy gosudarstvennyy istoricheskiy arkhiv [Russian State Historical Archive], F. 500, Op. 1, D. 822.

31. S doneseniyami o proisshestviyakh po Min. imp. dvora [With Reports on Accidents in the Ministry of Imperial Court]. Rossiyskiy gosudarstvennyy istoricheskiy arkhiv [Russian State Historical Archive], F. 472, Op. 48, D. 716.

32. Smeta dokhodov i raskhodov Ministerstva imperatorskogo dvora na $1917 \mathrm{~g}$. [The Estimates of Income and Expenditure of the Ministry of the Imperial Court in 1917]. Rossiyskiy gosudarstvennyy istoricheskiy arkhiv [Russian State Historical Archive], F. 468, Op. 17, D. 2459.

33. Smirnova-Sazonova S.I. Dnevnik za 1917 g. [Diary for 1917]. Rukopisnyy otdel Instituta russkoy literatury RAN [The Department of Manuscripts of the Institute of Russian Literature of the Russian Academy of Sciences], F. 285, no. 65.

34. Smirnova-Sazonova S.I. Dnevnik za 1917 g. [Diary for 1917]. RO IRLI, F. 285, no. 66.

35. Spisok chinov Ministerstva Imperatorskogo Dvora. 5 Sentyabrya 1910 goda [A List of the Officials of the Ministry of the Imperial Court. September 5, 1910]. Saint Petersburg, T-vo R. Golike i A. Vilborg Publ., 1910. 785 p.

36. Stakhovich Mikhail Aleksandrovich [Mikhail A. Stakhovich]. Gosudarstvennaya duma Rossiyskoy imperii: 1906 - 1917: Entsiklopediya [The State Duma of the Russian Empire, 1906-1917: Encyclopedia]. Moscow, Rossiyskaya politicheskaya entsiklopediya Publ., 2008, pp. 587-588.

37. Frenkel E.A. Anketa s otvetami na voprosy KBS [Questionnaire with Answers to KBS Questions]. RO IRLI, F. 377, Op. 7, no. 3732.

38. Khronika [Chronicle]. Birzhevye vedomosti (vecherniy vypusk) [The Stock Exchange News (Evening Edition)], March 16, 1917.

\section{Information about the Author}

Petr N. Gordeev, Candidate of Sciences (History), Associate Professor, Herzen State Pedagogical University of Russia, Naberezhnaya reki Moyki, 48, 191186 Saint Petersburg, Russian Federation, petergordeev@mail.ru, https://orcid.org/0000-0003-2842-4297

\section{Информация об авторе}

Пётр Николаевич Гордеев, кандидат исторических наук, доцент Российского государственного педагогического университета им. А.И. Герцена, Набережная реки Мойки, 48, 191186 г. СанктПетербург, Российская Федерация, petergordeev@mail.ru, https://orcid.org/0000-0003-2842-4297 